\title{
ELLISON'S INVISIBLE MAN: A JOURNEY FROM INVISIBILITY TO SELF DEFINITION
}

\author{
Rajendra P. Tiwari*
}

\begin{abstract}
This article concerns with the causes of the loss of identity and the ways to establish the identity of the African Americans in the United States as revealed in Ralph Ellison's Invisible Man. The article contents that the sense of racial discrimination in the white and the weaknesses among the black are the causes for the suffering and establish self identity of the black as revealed by the unnamed narrator of the novel. It explores the protagonist's journey to find ways to come out of the suffering and establish self identity. It reveals how the narrator attempts to prove himself by contributing to the society as a complex individual rather than following the prescribed roles of the system of the society.
\end{abstract}

Key words: Racial discrimination, invisible men, servility, radicalism, self definition, identity, African American.

INTRODUCTION

Published in 1952, Invisible Man is Ralph Ellison's first novel that won National Book Award for fiction in 1953. It contains a Prologue, twenty five chapters and an Epilogue. It presents the narrator's quest for freedom and self definition in a colour conscious American society. The word 'invisibility' refers to the situation of the Afro-Americans, who are not accepted as individuals but as stereotypical savages by the white Americans, who have racial prejudice. Here, in this novel, invisibility occurs when the white people in the United States refuse to see the narrator as an individual but as a stereotypical black boy to be humiliated and used for fun. This situation results in the loss of his identity. As Peter B. High points out, "The hero is ... invisible because ... whites cannot see blacks as individual people" (215). Through experience of suffering, humiliation and violence, the narrator realizes that he has to reaffirm his identity. He also realizes that in order to establish his identity and overcome suffering, he has to prove himself by exerting his power. Then he decides to make contribution to the society as a complex individual, in his own way; he refuses to comply with social sites available to him. Thus, he acts on his own rejecting the prescribed stereotypical roles and establishes his self identity.

Moreover, he also realizes that it is not only the white folks but the black themselves who are also responsible for their invisibility. It is because there is disparity among the blacks, who are not ready to cooperate to each other due to ignorance and selfishness. The novel reveals that the protagonist becomes aware of his lapses and also understands the weaknesses of his fellow black, especially their servile attitudes to the whites or radical in their efforts to get rid of their situation. He finds that both servility and violence arte wrong on the part of the black folks. The

Mr. Tiwari is an Associate Professor at English Department, Prithivi Narayan Campus, T.U., Pokhara, Nepal. 
narrator, therefore, chooses the middle path, the silent and furtive way, as suggested by his grandfather.

Vanspanckeren finds that the novel "embodies a powerful racial theme because the 'invisible man' is invisible not in himself but because of others, blinded by prejudice, cannot see him for who he is" (99-100). She points to the injustice that prevails in American society.

Similarly, Hart opines that the novel traces the life of a young Blackman trying to find himself as an individual as well as in relation to his race and society" (122). In search of companionship, success and his identity the narrator experiences racial prejudice throughout the novel in his journey

If the novel presents instances of white racism and the weaknesses of the blacks for the loss of identity or invisibility, what are those instances and weaknesses? What does the narrator face or suffer during his journey from the south to the north in an effort to find success in life? What are the ways that he adopts and what is his final step that he determines to follow to achieve his goal? These are the basic questions among many others that this article attempts to find answer.

\section{ANALYSIS AND DISCUSSION}

\section{RACIAL DISCRIMINATION AND LOSS OF IDENTITY OF THE BLACK}

Ellison presents the first person narrator who starts with the declaration that he is invisible and explains what he means by "invisible". He states that he is invisible because people refuse to see him (Invisible Man 7). His invisibility occurs by virtue of others' reaction toward him. That is, they do not accept him as an individual. The white racists behave towards him as a savage. They take him in the usual stereotyped image of the black rather than an individual citizen. This situation of invisibility, as High adduces, points to the injustice and absurdity of American society (217). It is because most of the black Americans because of the racist society where the white hold dominant position experience this reality.

Although the novel was written in the mid-twentieth century long after the abolition of slavery, it presents white society's treatment of the African Americans as being little better than that of the slave masters. The narrator's grandfather describes the white society as a circus lion, a vicious beast, in whose presence one is always in danger of being killed. Ellison gives a description of how the black boys are made to fight blindfolded among themselves and humiliated at a nude dance of a white lady for the fun of the so-called respectable whites. The narrator is invited to deliver his speech to the town's leading white people that included bankers, doctors, judges, lawyers, merchants, teachers, etc at the main ballroom of a hotel. Before the speech he has to face the nude dance and "battle royal" among ten black school boys.

In the fight scene, chairs are arranged around three sides of a portable boxing ring where the white men drunk on whiskey are seated. The narrator almost wets his pants due to the strong smell of tobacco and whiskey; in the centre of the floor a drunk naked lady is ready for a dance (Ellison, 408). Some of the boys lower their heads, trembling. The narrator looks at her and feels a wave of guilt and fear. Her body is powered. He sees her breasts are round and firm, and the nipples erect. He wants to feel her soft thighs and love her. Some white men order the boys to look at her while other whites not to, in threatening tone. Ellison writes, "Some threatened us if we looked and others if we did not" (408). The boys are confused and terrified. One 
boy faints. When the naked lady starts dancing provocatively, the largest boy in the group, trying to hide his erected organ with his boxing gloves, pleads for permission to go home. His fear is aroused by the threat of being lynched if he shows sexual interest toward a white woman. The white men become a near-frenzied mob, who chase her hysterically and toss her around as she tries to flee. One of the white men, describes the narrator, as "an intoxicated panda" (409). They behave as animals.

The image of the white men is seen as wolves, "howling red faces", implying the vicious nature of their racism, and exploitation of black folks like the Negros boys. The white woman is not treated as a human being but as an object, a doll, part of the circus-like entertainment for the fun of the white men.. She is also exploited and humiliated. The black boys are defenseless. This episode presents the example of racism and male chauvinism among the whites. When the black boys try to leave they are ordered to get into the ring. They are compelled to do what they are told. All the ten boys are blindfolded at the end of the nude dance. The boys cannot see. Their not being able to see due to the bands of white cloth suggests that the obstruction to the black is created by the white. Now they are told to strike blows among each other. The narrator feels blow from all sides and warm blood everywhere, and he stumbles. The fight gives the white delight and suffering to the black boys. The boys are presented as circus animals for the fun of the white folks. The narrator describes the torture of the boys:

I glimpsed a boy violently punching the air and heard him scream in pain as he smashed his hand against a ring post. For a second I saw him bent over holding his hand then going down as a below caught his unprotected head.... I bled from both nose and mouth, the blood spattering upon my chest (Invisible Man 26).

The narrator manages to see through the blindfold by partially loosening it and describes the torture of the Negro boys and that of himself as a result of the inhumanness or cruelty of the white folk.

Another racist and humiliating treatment on the black boys by the white men is to make the boys collect fake gold coins scattered on the electrified rug for the prize. The boys are lured and made to fight with each other for the coins. When the boys try to avoid the rug, the white men push them into the rug. It gives them entertainment to see the black boys suffer and cry with pain. One of the students is lifted into the air and dropped to flush and yell on the charged rug. The narrator describes the moment of his pain and the suffering of his fellow students as well as the delight of the white men as:

A hot violent force tore through my body, shaking me like a wet rat... The men roared above us as we struggled.

"Pick it up, goddamnit, pick it up!" someone called like bass voiced parrot. "Go on, get it!"...

Suddenly I saw a boy lifted into the air glistening with sweat like a circus seal, and dropped, his wet back landing flush upon the charged rug, heard him yell and saw him literally dance upon his back,... his muscles twitching like the flesh of a horse stung by many flies (413).

Ellison describes himself as a rat while struggling on the charged rug. Rats are lowest creatures who survive by scavenging or scrambling for food. This imagery implies that the black in the United States are not given dignified means of supporting themselves in the white society. Similarly, the white men shouting at the black boys are no better than parrots, mindlessly repeating the racist words and deeds perpetuated by white society, without any consideration. Parrots mimic words without knowing the 
meaning or importance of what they are saying. Likewise, the black boy is compared to a horse, a beast of burden kept by humans to serve their ends. It suggests that the Negroes have been used by the white for physical labour. The white are like flies which sting the black (horse) and which are dangerous because they are many in number.

As the narrator tries to avoid the shock from the rug, a white man pushes him time and again into the rug. The coins turn out to be worthless brass tokens advertising an automobile. After being subjected to such horrible deeds of humiliation, the narrator is told to give his speech which will decide scholarship for him to study in a State Negro College. During the speech he is made a laughing stock. The white show different behavior towards the black to control them. Sometimes they humiliate, sometimes they threaten and sometimes they praise the blacks to make them work according to the will of the white. Before the narrator delivers his speech, the MC praises the young narrator, saying, "I'm told that he is the smartest boy we've got out there in Greenwood. I'm told that he knows more big words than a pocket-sized dictionary" (Ellison, Battle Royal 414). These words of praise are not genuine but only a ploy to make him subservient.

His speech is a conventional appeal to African-Americans to be friendly towards whites and to accept the status quo. The white folks donot pay attention to his speech but go on laughing and talking which makes him shout with extra effort until his mouth is filled with blood and he coughs. He intends to stop and go to the sandfilled spittoon to relieve himself but he notices that the superintendent and some others are listening to him and he is afraid. Despite the pain, he speaks louder, gulping the blood and saliva together. He feels that his speech has become a hundred times longer than the previous day. Inadvertently, he utters the phrase "social equality" instead of "social responsibility" which makes the white folks cautious and he corrects himself. They do not like even to hear the word "equality" from the mouth of a black, let alone treating them on the equal him. They expect subservience, humility and endurance from the black folks. The narrator begs for their forgiveness for his mistake, and his humility is rewarded with applause, a calfskin briefcase and a scholarship to the State College for Negroes.

The narrator's days in his college further deepen his experience about white racism. Mr. Norton, one of the white founders and a trustee of the Negro college, apparently looks to be sympathetic to the Negroes but in reality, he is a white racist. He admits that the Negroes are responsible for that fate, but he takes advantage of the poor black women. He tells the narrator, "Your people were somehow closely connected with my destiny. That what happened to you was connected with what happen to me" (Ellison, Invisible Man 42). He looks kind to the narrator. But he is a person of dubious character. He employs black women for work but does no pay them. For instance, when the narrator takes Mr. Norton to the cabins and Golden Day for a visit, he hears black women expressing anger towards him. One of the women yells, "Give it to him good! He never pays me! Kill him!" (78). The girls who serve him do not respect him due to his greed and sexuality. Edna, a lady in the bar, says to her friend," Girl don't you know that all these rich ole white men got monkey glands and billy goat balls? Thee ole bastards don't ever get enough. They want to have the whole world" (81). Edna seems aware of the white men's avarice and sexual instinct, and the white's exploitation of the black. A black man addresses him as father and another one as 
grandfather. The conversation of the two black men illustrates this. Pointing to Norton, one man claims.

Gentlemen, this is my grandfather.

But he's white; his name's Norton."

No, no, that was my father," another person argues (73).

The expression of the two black men shows that Norton has illicit relation with many black women. He exploits their labour making them work until he quenches his sexual desire. Then he fires them. Mr. Norton orders Dr Bledsoe to punish the narrator for taking him for the visit where he gets humiliated and sustains a minor injury on the forehead. Bledsoe chides and expels the narrator from the college.

The Invisible Man indicates that the whites of the South not only exploit and dominate the black, they also cannot tolerate the health, wealth, skill and dignity of the black. The narrator describes what the vet tells him about what the white did to him, "Ten men in masks drove me out from the city at midnight and beat me with whips for saving a human life. And I was forced to the utmost degradation because I possessed skilled hands and that my knowledge could bring me dignity not wealth, only dignity, and other men health" (86). This description illustrates that the white cannot tolerate to see the progress and equal position of the black.

The narrator goes to the North from the South in search of a better life. However, in the cosmopolitan atmosphere of New York, he is victimized and his dreams are shattered. He experiences the adverse forces of racism there too. The whites are the factory owners and the blacks are the workers in their factories. They are made to work for cheap wages and are fired for small mistakes. The narrator at first works in Liberty Paints but he is fired for being an unskilled hand. He finds a job in another company where he has to work along with Luscious, an old skilled dutiful black man, whose role is very important in the company. Yet, the narrator thinks, this skilled man's job is also not secure; if they find some white skilled labourer, he will be fired any time. When the narrator goes on thinking about the old man and the cruelty of the white masters, the boilers in the factory explode and he loses his consciousness. When he comes to sense, he finds himself in the factory hospital.

In the hospital he feels that the white doctors' treatment is guided by colour consciousness. He listens to their conversation about the mode of diagnosis and treatment. One of the doctors says, "I think I still prefer surgery. And in this case especially, with this uh... background" (206). The argument of the doctor makes him feel that white doctors treat the black patient differently. The black are used for experiment as the animals. He finds that they experimented on him new medicines, machines and new mode of diagnosis.

While walking along the streets of New York, the narrator observes an advertisements of the cosmetic products. The advertisement states, "You too can be beautiful. Win greater happiness with whiter complexion" (228). In this ad, whiteness is related with beauty and happiness, implying that blackness is the opposite. Moreover, he sees a black woman crying, holding the Bible in her hand. Her belongings are scattered on the street and the white men in the crowd carrying her goods, without showing any sympathy to her. She asks the white men for permission to go inside to pray. One of the whites, says, "I can't help it lady. You'll have to do 
your praying out here" (238). The narrator knows that the old lady wants to pray inside but she is not allowed. The narrator helps the lady and her husband to enter the house, and he gives a lecture to the crowd against the cruelty of the whites. Brother Jack offers him the membership of the Brotherhood, an underground organization. But he finds that it is not genuinely working for the blacks rather it is dominated by the interest of the whites. As he works in his own way, he is accused of attempting to dominate and overshadow the organization.

The black folks were hopeful of their bright future or upliftment after the declaration of independence and the draft of the constitution. Ellison writes, "Yes these old folks had a dream book. But the pages went blank and failed to give them the number. It was called the seeing Eye, The Great Constitutional Dream Book..." (243). The black dreamt of equal rights, opportunities and security but their aspiration, desires and hope did not materialize. It cause are frustration among the black. They work hard but their situation does not change. Ellison reveals through Invisible Man the causes being racist attitude in the white and the defect of the black themselves.

\section{PROBLEMS WITHIN THE BLACK FOLKS}

Before the abolition of the slavery, the narrator's grandparents were born as slaves; after the abolition, they got freedom that made them rhetorically part of the United States, but in social sphere they were separated from the whites, and they were denied of citizenship and identity. They were unable to enjoy freedom and equal opportunities. It is not only the white folks' racist attitude for the loss of the black's identity, freedom and equal opportunity, but also the weaknesses among the black folks themselves. Some of the weaknesses are humility, endurance, servility, selfishness, lack of cooperation, skill and extreme radicalism. Instead of respecting and seriously following the suggestion given by the experienced old members of their own race or family, the black folks following the prevailing white doctrine.

Ellison, in his interview with Chester and Howard says, "The major flaw in the hero's character is his unquestioning willingness to do what is required of him by others as a way to success, and this was the specific form of his "innocence." He goes where he is told to go; he does what he is told to do; he does not even choose his Brotherhood name. It is chosen for him and he accepts it. He has accepted party discipline and he cannot question their decision" (191). For the first twenty years of his life, the narrator has looked to others to answer questions of self definition. He was looking for himself by asking others not himself. He admits, "I'm not ashamed of my grandparents for having been slaves. I am only ashamed of myself for having at one time been ashamed" (Ellison, Invisible Man 10). He feels ashamed after discovering himself as an invisible man after a long time.

The narrator remembers the advice that his grandfather gave to his son, the narrator's father, to continue the black folks' fight with the whites secretly as traitors and spies. He said:

Son, after I'm gone I want you to keep up the good fight.... Our life is a war and I have been a traitor all my born days, a spy in the enemy's country ever since I give up my gun back in the Reconstruction. Live with your head in the lion's mouth. I want you to overcome'em with yeses, undermine'em with grins, 
agree'em to death and destruction, let'em swoller you till they vomit or bust wide open... learn it to the younguns (19-20).

Grandfather's suggestion hints that the black folks' life is like that of circus entertainers who risk their life for survival, playing with the dangerous beasts (implying the white). He also suggests that the black folks should behave apparently as "yes men" enduring all tortures and humiliations but inwardly they should work as spies or traitors.

The narrator is alarmed, disturbed and confused by the old man's words. He has been praised by the powerful white men for his meekness, specially for his speech on his graduation day, in which he focused on humility; he expressed that humility was the secret of progress. He is perplexed as to how he should behave with the whites. He narrator says:

It became a constant puzzle which lay unanswered in the back of my mind. And whenever things went well for me I remembered my grandfather and felt guilty and uncomfortable... I was praised by the most lily-white men of the town. I was considered an example of desirable conduct- just as my grandfather had been .... It made me afraid that some day they would look upon me as a traitor and I would be lost ... The old man's words were like a curse (Ellison, Battle Royal 406).

He wants to look good in the eyes of the white folks and endures all the tortures and tension. He follows unquestionably the path indicated by others in order to get succeed in life. He lacks the ability to anticipate actions and behaviours of people, and to act accordingly.

The Battle Royal scene presents not only the inhuman treatment of the white toward the blacks, it also presents the weakness of the backs. It shows that the latter fight among one another in order to please the white by providing them with entertainment at the cost of their dignity and life. They fight among themselves for petty prizes. Moreover, Tatlock, the biggest among the black school boys, is not ready to cooperate with the narrator when the latter proposes to fool the white by making a fake fight and by not injuring each other. It is not only Tatlock but the narrator himself is also responsible for the miserable situation at the boxing ring because the narrator is also influenced by the corrupting attraction of prize and praise. He wants to be a winner instead of offering the opportunity to Tatlock, who is bigger and stronger than he. It implies that the blacks are not ready to cooperate with one another but they react in response to social Darwinism, which encourages individuals to fight to the finish in order to achieve rewards.

The narrator wants to bribe Tatlock. The following conversation between the narrator and Tatlock illustrates this the point:

I whispered "fake fight I knocked you out, you can have the prize."

"I'll break your behind," he whispered hoarsely.

"For them?"

"For me, sonofabitch!"...

"I' 11 make it five dollars more."

"Go to hell."...

"Seven."

"Give it to your ma," he said, ripping me beneath the heart (Ellison, Battle Royal 411-12). 
The narrator is sure that Tatlock is stronger than he and will win the fight. Therefore, he offers Tatlock money in addition to the prize and pretends to lose the fight. Tatlock refuses it.

Furthermore, during the blindfolded fight, the narrator manages to partially loosen his blindfold and causes the blows aimed at him to strike his fellows. He describes, "I played one group against the other, slipping in and throwing a punch then stepping out of range while pushing the others... to take the blows blindly aimed at me" (411). This implies that the behaviour of the black is guided by selfish motive and one is ready to inflict suffering or injury to another.

Dr. Herbert Bledsoe, the Negro president, who takes over the local black college, works slavishly under Mr. Norton, the white founder and trustee of the college. He depicts Norton as possessing "the power of a king or in a sense of God" (Ellison, Invisible Man 45). At Norton's command he expels the narrator from the college. Bledsoe believes that the black folk should work hard, adopt the speeches and manners of the whites, and please them in order to succeed in life because the whites are deemed superior to the black. He accuses the narrator of destroying the institution and its reputation by taking Mr Norton to visit the poor blacks.

Bledsoe regards the white as god and humiliates the blacks as being liars and destroyers. He humiliates the blacks by using derogatory terms as "Nigger," "black bastard," and so on. He says to the narrator, "Nigger, this is not the time to lie. I'm no white man. Tell me the truth" (124). Although the narrator talks to him sincerely and truthfully, Bledsoe unnecessarily reprimands him. He wants to impress the white boss by dominating the black students. He blames the narrator for not knowing anything than destroying. He says, "College for Negroes! Boy, what do you know other than how to ruin an institution in half an hour that it took over half a hundred years to build?" (205). This expression shows that Bledsoe's activities are guided by selfish motive for personal gain, especially the lust for power to rule over his own race.

Bledsoe knows that the white's treatment toward the blacks is not fair, but he has no courage to protest because he is afraid of their power. He tells the narrator:

You are a black educated fool, son. These white folk have newspaper,

magazines, radios, sports man to get their ideas across. If they want to tell the world a lie, they can tell it so well that it becomes the truth, and if I tell them that you're lying, they will tell the world even if you prove you're telling the truth (128).

Dr. Bledsoe knows that the white folks have absolute control over the administration, industrial enterprise, educational institutions, the mass media, etc. He knows also about the injustice done to the black but the does nothing to help the people of his race. Instead he warns the narrator and instructs him not to protest.

Bledsoe's servility does not end only by expelling the narrator from the college, it also extends in sending seven letters to his school friends in New York for winning the grace of the white folks by convincing them that he is not working in favour of the blacks but in favour of the writes. A letter reads like this:

My dear Mr. Emerson:

The bearer of this letter is former student of ours... who has been expelled for a most serious defection from our strictest rules of department... thus... it is highly important that his severance with the college be executed as painlessly as 
possible. I beg of you, sir, to help him continue in the direction that promise which like the horizon recedes ever brightly and distantly beyond the hopeful traveler. Respectfully I am your humble servant Herbert Bledsoe (167-68).

The narrator expects that the letter will help him provide with better opportunities to study in a college in New York. But contrary to his expectation, it contains suggestion for giving him more punishment.

The black people are caught up in the vicious circle. Their poverty and lack of skill in the profession block them for their progress and force them to indulge in criminal activities and the lose their dignity and self respect. Jim Trueblood commits incest with his own daughter. As to the cause or the environment of the incest Trueblood argues: "You see, suh, it was cold and us did not have much fire. Nothin' but wood, no coal. I tried to git help would not nobody helps us and I could not find no work or nothing. It was so cold all of us had to sleep together; me, the ole lady and the gal. That's how it started, suh" (53).This immoral activity is the result of poverty and a situational mistake. He finds no job, no help but suffering in a cold atmosphere and a compulsive situation for crime. Trueblood's crime brings disgrace to himself, his wife, his daughter and the black community as a whole. It becomes a tool for the whites to exhibit the animalistic character of the blacks.

The narrator is not a skilled worker. He steals electric wires, bulbs and electricity to provide his room with light. Jobless people have no money and involve in criminal activity. In New York he is employed in Liberty Paints, an American industry but due to carelessness and lack of skill he is fired. His experience there is the true reflection of Negroes' experience in American industry.

As a member of the Brotherhood, the narrator performs his duty in his own way successfully for a month. Then he receives a letter from an unknown friend cautioning him about his speed and the danger that may befall on him. It reads:

\section{Brother}

This is advice from a friend who has been watching you closely. Do not go too fast keep working for the people but remember that you are one of us and do not forget if you get too big they will cut you down you are from the south and you know that this is a white men's world. So take a friendly advice and go easy so that you can keep on helping the coloured people. They don't want you to go too fast and will cut you down if you do. Be smart .... (332).

This letter is from one of his well-wishers, and the narrator realizes that he has gone too far and to fast. The members of the party have become jealous of him. True to the warning, Mr. Wrestrum, one of the members of the party, charges the narrator for attempting to dominate and overshadow the party. Thus, although the Brotherhood party is opened for the help of the black, it is ruled by the petty interest of the whites. The politics of the white is dominant, and they are applying the policy of "Use a Nigger to catch a Nigger." The narrator realizes that the black folks are unaware of this double standard which helps to prolong the white domination.

After he is charged with overshadowing the party, he goes to meet Tod Clifton, a former influential member of the Brotherhood. He sees that a police officer is following Clifton and Clifton hits the officer as the officer tries to arrest 
him; then the officer kills him (376-77). The narrator has no opportunity to talk to Clifton. He worries how he should react with the media about his death. He plans to arrange a grand funeral to save Clifton's identity and to arouse people's sentiment against the cruelty of the police. After the funeral, the narrator is asked to justify his actions in the meeting of the organization. They accuse Clifton of selling a degrading object and justify the police action. At this, the narrator finds that the Brotherhood is not genuine for the cause of the blacks. He realizes, "All our work had been very little, no great change had been made. And it was all my fault.... I'd forgotten to measure what it was bringing forth. I'd been asleep, dreaming" (384). He evaluates his own responsibility as its member and the activities of the Brotherhood to find that the result has been worthless.

In the Liberty Paints, the narrator works under Lucious Brockway, the black director, who dislikes the unions and parties. He thinks that the unions and the parties are after his job. One day when he knows that the narrator was late in his work due to his meeting with the union, Brockway gets angry and almost attacks the narrator, saying, "You... trouble-making union louse... The Lord being my witness, I'll KILL YOU!" (197). He thinks that the unions create trouble. They are not for his help. He expresses his hatred of the union: "That damn union, that damn union! They after my job! I know they after my job!... the chickenshit bastards" (199). Brockway feels that the unions work against the holders high position. He has groundless hatred towards them. This points to the fact that there is disparity among the blacks. The higher position holders think that the unions are against them while the labourers hold that the unions work under the influence of the white.

The narrator finds that members of the Brotherhood are jealous of his popularity and they accuse him of being an opportunist inclined to advance his own interest. He is prevented from doing his task in Harlem as his fame grows (346). Later on, he is called back to control over Ras's activity. Ras is a radical member of the party, who leads a group of people to fight against those who or support the whites. Again the narrator's decision of arranging grand funeral of Tod Clifton and creates tension in the Brotherhood. Jack tells the narrator that he is not hired to think but to perform the task as instructed (405). Now the narrator feels that people like Jack take him as a cog in a machine that does not think but acts as directed.

On the other hand Ras criticizes the narrator for not working for the liberty of the black people but for following the manners of the white and their supporters. The narrator hears what Ras says:

\footnotetext{
Never mind, take your corrupt ideology and eat your own guts like a laughing hyena.

You are nowhere mahn nowhere! Ras is ... fighting for the liberty of the black people when the white folks have got what they want and done gone of laughing in your fee and you stinking and chocked up with white maggots (325-26).
}

Ras thinks that the narrator is not aware of the white domination and loss of his identity. The narrator silently leaves the place, finding nothing to say in his defense. Two of Ras's men follow him and punch him. The doorman that the movie theatre helps him to get rid of them. 
When there is a race riot in Harlem, many people are killed and a lot of property is destroyed. Ras turns himself into a destroyer. The blacks are betrayed by the blacks. Ras orders his men to hang the narrator "to teach the black people a lesson, and there be no more traitors, No more Uncle Toms. Hang him up theer with them blahsted dummies!" (492). The narrator hides himself behind a hedge and saves himself at this critical moment. The narrator disguises himself as Rinehart in his attempt to save himself from the attack of Ras's men. He is between the two groups of the black: one, the aggressive group of Ras and the other, the servile group of the Brotherhood. The former group attacks all the white and the black whereas the latter serves the white under the guise of Brotherhood. Both the groups do not do good for the oppressed blacks.

\section{ASSERTION OF SELF IDENTITY}

Invisible Man presents the instances of white racism and the loss of identity of the black folks in the United States. By presenting the experiences of an unnamed narrator it also serves the function of, as Singh holds, "consciousness raising attempts aimed primarily at black readers that expose the risk of a life lived on borrowed definitions" (141). For the first twenty years of his life, the narrator has looked to others to answer questions of self definition. He is subservient and seeks for the praise of the white folks for his humility. He endures humiliation, torture and suffering for scholarship to study in the state college for blacks. He realizes that he is an invisible man or has no identity as others do not recognize him as an individual but as a stereotyped black. He is puzzled to remember his grandfather's statement as to how he spent his life in relation to the white and his advice to his father and the black folks to work as a spy and traitor. He is disturbed by the old man's words as he has been praised by the powerful white men for his meekness. But late on he carries out his grandfather's advice.

The nameless narrator is a naïve black boy makes a journey from the South to the North in an effort to discover his identity. He learns through suffering and interactions. As Ellison says in his interview with Chester and Howard that the novel is "about innocence and human error, a struggle through illusion to reality" (190-91). The naïve and meek narrator discovers that it is he himself who can figure out who he is. He realizes the meaning of his grandfather's advice that their life is a life of warfare and that they have to live with their heads in the lion's mouth.

Although the narrator initially gives a lecture requesting his folks to be humble and friendly to the white, he later on begs for forgiveness for inadvertently uttering the phrase "social equality" before the white folk, looks overjoyed for being rewarded with a calfskin briefcase and a scholarship for study, he is not happy with these things. His dream the next night exhibits his unconscious mind in which he sees he is at a circus with his late grandfather who refuses to laugh at the humorous activities of the circus clowns. This implies that the boy feels that his grandfather is not happy with his action as his action is like that of the clown. He feels that he is being humiliated by the white. He feels the loss of identity but does not come to rebellion as he has to find himself firstly through study. His finding the message "Keep This Nigger-Boy Running" 


\section{ELLISON'S INVISIBLE MAN: A JOURNEY FROM ...}

(Ellison, Battle Royal, 417) in dream suggests his unconscious awareness about his being humiliated by the white folks. He feels that both he and Tatlock play the stupid clowns. However, he gives first priority to study to discover himself.

He finds that he is invisible because the world is full of blind people who cannot see his real self. Another factor he finds is to be unable to act according to one's own notion and wanting to please others and acting according to their will is to lose one's personality or identity. Moreover, he comes to realize that one has to be skilled and careful in one's profession and actions to avoid errors and mistakes. One can establish one's identity, power and ability by developing one's professional skill and alertness. He loses his job at Liberty Paints due to the lack of skill and carefulness.

Similarly, he comes to know by experience that he has been a victim, as other black folks, of the two extremes: servility and radical violence represented respectively by Dr Herbert Bledsoe and Ras. Both groups of people are a hindrance in the free progress of the black. He earns his fame/popularity in Harlem or New York when he starts working on his own, without depending upon others. He thinks about his identity and realizes that he is playing a game like a clown to amuse the white. This makes him feel sly and cautious to solve his mystery. He says, "I could no more escape than I could think of my identity. Perhaps, I thought, two things are involved with each other. When I discover who I am, I'll be free" (Ellison, Invisible Man 212). He decides to find himself first and then be free. He can live a free life only by proving himself. He has to be skilful, careful and avoid wrongs in actions to prove his ability and power.

On the contrary to his graduation day speech and that of the following day delivered before the white folks, the narrator protests, against white domination in the street of New York, in favour of a black couple to let them pray inside the church house and delivers a lecture. He screams loudly, pushes the couple inside and gives a speech to the crowd gathered there against the cruelty of the white. Here he makes the crowd come to action for demonstration rushing the white and carrying the belongings of the black couple inside the house. He works on his own to help the poor black of Harlem as a member of the Brotherhood. But after Tod Clifton's murder he comes to realize the worthlessness of the organization, which is under the domination of the white folks and the submissive blacks. He realizes that Brother Jack has used him as a tool to work under him as a $\operatorname{cog}$ in the machine and he would deceive the Harlem people he continues to work under Brotherhood. Then he rejects to work for their interest and decides to work on his own.

He determines to emerge from his underground hibernation, not to deceive and not to be deceived. He will do something to come out of his invisible state and compel others to see him. Ellison describes the narrator's realization and decision, as:

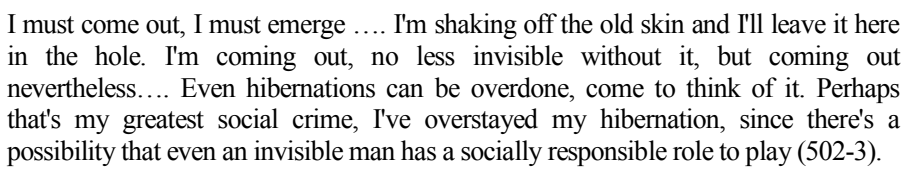


Now he understands his grandfather's advice in full circle. He realizes his state of deep sleep, causes of invisibility, and the ways to come out of it. He feels that he has committed a crime by not realizing these things so long and that he can find himself by making contribution to the people or performing his social responsibility. He has to come out of the hole, metaphorically, the state of invisibility. He will not follow the path of others but will pave a path of his own to define himself. He will do something for the downtrodden as a complex individual.

\section{CONCLUSION}

Ralph Ellison's Invisible Man is the story of a nameless first person narrator, a naïve black boy, who has bitter experiences of racism and loss of identity and who makes a journey from the south of the United States of America to the north, New York, in his attempt to seek his identity or find himself. He is at first humble and servile to the white racists and through his suffering and humiliation, he learns how his identity in particular and that of the whole African Americans in general in the United States is in crisis or invisible. He learns through his interactions with the white as well as the black folks that it is not only the white but also the black who are responsible for their invisibility or loss of identity or dignity.

The whites humiliate, dominate and use the black for their entertainment and other advantages and they are not ready to recognize the black as complex individuals. The black too are not ready to cooperate with one another due to their selfish motives. There is disparity among the black as high position holders, who are servile to the white and dominate the black, and the poor ones who bear double domination. Moreover, the black are obsessed with the desire to win each other and to impress the white for hollow praise and prize. Likewise, their poverty stricken situation and lack of skill and ability results in committing crime, errors and mistakes. This further results in their lack of discovering themselves.

The narrator is perplexed at first about his ways to come out of the situation. He is servile to the white for praise and prize, and fights with his own black fellows as he is obsessed with his desire to win them. Later on he understands the drawbacks of being servile and his grandfather's message to the black folks to apply furtive way for their freedom. He also understands the fake support of the white through an underground party Brotherhood as well as the danger and defects of aggressive/radical way. Finally, he comes to decide his way for his freedom and self definition and to get rid of the state of being invisible. He determines to emerge from his hibernation and exert his power to prove himself by making useful contribution to his society as a complex individual in his own way not looking to others for his definition but to himself. Thus, this novel is a journey of a naïve young man from his state of invisibility to self definition.

\section{WORK CITED}

Bone, Robert A. (1972). "From the Contemporary Negro Novel." The American Novel: Criticism and Background Readings. Ed. Christ Wegelin, The Free Press, New York, pp. 526-42. 
Ellison, Ralph (1984). "Interview by Chester, Alfred and Vilma Howard." Writers at Work: the Paris Review Interviews. $6^{\text {th }}$ Series. Ed. Plimpton, George, The Viking Press, New York, pp. 181-96.

Ellison, Ralph (1997)."Battle Royal". Elements of Literature. $4^{\text {th }}$ ed. Ed. Scholes, Robert, et al., Oxford UP, New Delhi, pp. 405-17.

--- (1994). Invisible Man. The Modern Liberary, New York.

Hart, James D. (1986). The Concise Oxford Companion to American Literature. Oxford UP, New York.

High, Peter B. (1997). An Outline of American Literature. Longman, London.

Hobson, Christopher Z. (2005). "Invisible Man and African American Radicalism in World War II". African American Review. 39: 355-65.

Ruland, Richard and Malcolm Bradbury (1992). From Puritanism to Postmodernism. Penguin, New York.

Singh, Amritjit (1981). "Self Definition as a Moral Concern in the Twentieth Century." Afro-American Novel: A Collection of Critical Essays. Ed. B.M. Malla, Kalyani, New Delhi, pp. 138-56.

Vanspanckeren, Kathryn (1994). Outline of American Literature. United State Information Agency, New York. 